\title{
KEUNTUNGAN USAHATANI PADI SAWAH DAN TERNAK ITIK DI PESISIR DANAU TONDANO KABUPATEN MINAHASA
}

\author{
D. Polakitan* Arie Dp. Mirah**, Femi H. Elly**, dan V.V.J.Panelewen** \\ Fakultas Peternakan Universitas Sam Ratulangi Manado, 95115
}

\begin{abstract}
ABSTRAK
Penduduk yang bermukim di pesisir Danau Tondano, mayoritas penduduknya mengusahakan tanaman padi sawah dan sebagian mengusahakan ternak itik. Pengusahaan tanaman padi pada lahan sawah secara monokultur sepanjang tahun tanpa dibaringi dengan diversifikasi akan mengurangi tingkat produktivitasnya. Peningkatan pendapatan keluarga tani melalui kombinasi usahatani padi dengan ternak itik akan mempengaruhi kelestarian lingkungan hidup. Penelitian ini bertujuan untuk menganalisis keuntungan kombinasi usahatani padi sawah dan ternak itik di Pesisir Danau Tondano. Metode pengumpulan data yang digunakan adalah metode survey dan pengamatan langsung di lapangan. Jenis data yang dikumpulkan adalah data time series dan cross sectian. Penentuan petani sampel secara Simple Random Sampling. Penentuan responden secara Purposive Sampling dengan kriteria adalah petani yang memiliki kombinasi usahatani padi sawah dan ternak itik. Berdasarkan kriteria tersebut ditentukan 10 (sepuluh) sebagai responden. Penerimaan kombinasi usahatani padi dan ternak itik sebesar Rp 75.546.633 per tahun dan biaya yang dikeluarkan $\mathrm{Rp}$ 26.532.737 per tahun. Analisis data yang telah dilakukan
\end{abstract}

*Mahasiswa PPS Unsrat

** Fakultas Peternakan Unsrat menggunakan analisis keuntungan dilanjutkan dengan analisis $\pi / \mathrm{C}$ ratio. Berdasarkan hasil penelitian menunjukkan bahwa nilai $\pi / \mathrm{C}$ ratio sebesar 1.54. Kesimpulannya usahatani padi yang dikombinasikan dengan ternak itik memberikan keuntungan yang memadai dengan $\pi / \mathrm{C}$ ratio lebih besar satu. Saran yang disampaikan agar usahatani padi sawah sebaiknya dikombinasikan dengan usaha ternak itik.

Kata kunci: Keuntungan, padi sawah, itik, kombinasi usaha

\section{ABSTRACT}

FARM PROFIT OF DUCK AND PADDYWET FIELD AROUND TONDANO LAKE OF MINAHASA REGENCY, NORTH SULAWESI. The population majority inhabiting around Tondano Lake planted paddy-wet filed and raised duck animal. Mono culture system of this plant without diversification of other plants decreased its plant productivity. Increasing income of household farmers by combination of duck integration farm affected conservation of the environmental farm. The objective of this research was to analyze farm profit by combination of paddy-wet field and duck animal of household farmers around Tondano Lake. Data were collected using survey method by observing directly on the paddywet field location around Tondano Lake. Types of data were time series and cross section. Samples of household farmers used in this study were defined using simple random sampling. The respondents were defined by 
purposive sampling method with the criteria of them to have the combination farm of paddy-wet field and duck animal. Based on this criterion, there were ten respondents. The incomes of farm combination between paddywet field and duck animal were IDR $75,546,633$ per year with the total cost of IDR $26,532,737$ per year. Data analysis of income was done by $\pi / \mathrm{C}$ ratio analysis. Results showed that the $\pi / \mathrm{C}$ ratio value was 1.54 . It can be concluded that farm combination of paddy-wet field and duck animal yield profit of more than 1 of the $\pi / \mathrm{C}$ ratio, implying that farm diversification system should be applied by household farmers.

Keyword: Profit, paddy-wet field, duck animal, farm diversification system.

\section{PENDAHULUAN}

Penduduk yang bermukim di pesisir Danau Tondano, mayoritas penduduknya mengusahakan tanaman padi sawah dan sebagian mengusahakan ternak itik.Peningkatan produksi pertanian belum sepenuhnya memberikan hasil yang nyata terhadap peningkatan kesejahteraan petani, khususnya petani padi (Abduh dkk, 2003). Pengusahaan tanaman padi pada lahan sawah secara monokultur sepanjang tahun tanpa dibaringi dengan diversifikasi usahatani akan dapat mengurangi tingkat produktivitas lahan sawah. Hal ini disebabkan karena sifat fisika, kimia tanah akan terganggu yang akhirnya membawah konsekuensi terhadap pendapatan dan kesejahteraan petani. Adanya sistem kombinasi pertanaman padi-ternak itik sangat mendukung program pemerintah dalam penanaman padi diberbagai daerah untuk swasembada beras. Sistem IP 300 diharapkan terjadi peningkatan produksi beras, disisi lain terjadi peningkatan sumberdayapakan ternak seperti jerami padi, dedak dan menir. Introduksi ternak itik pada pertanaman padi sistem IP 300 diperkirakan dapat mengurangi gulma, serangga tanaman padi, keong penggangu dan dapat memberikan pupuk serta menstimulir pertumbuhan padi (Abdhu dkk, 2003).

Ternak itik digembalakan di lahan sawah yang baru selesai dipanen. Ternak itik tersebut mengkonsumsi sisasisa/limbah padi yang rontok waktu panen dan hewan-hewan yang terdapat di lahan sawah. Pada sore harinya ternak itik dikandangkan dan diberi pakan tambahan berupa renga (siput) yang diperoleh dari Danau Tondano. Petani sudah lama mengeluti usahataninya tetapi ternyata mereka belum mengetahui secara pasti apakah kombinasi usahatani yang mereka kerjakan memberikan keuntungan atau kemungkinan kerugian. Berdasarkan 
permasalahan tersebut maka telah dilakukan pengkajian untuk mengetahui tingkat keuntungan kombinasi usahatani di pesisir Danau Tondano Kabupaten Minahasa. Penelitian ini bertujuan untuk menganalisis keuntungan kombinasi usahatani padi sawah dan ternak itik di Pesisir Danau Tondano Kabupaten Minahasa.

\section{METODE PENELITIAN}

Penelitian ini dilaksanakan di Kabupaten Minahasa Propinsi Sulawesi Utara dengan menggunakan metode survey. Jenis data yang dikumpulkan adalah data time series dan data cross section. Adapun sumber data-data adalah data primer dan data sekunder. Data primer diperoleh melalui wawancara langsung dengan petani (responden) di lokasi, dengan menggunakan daftar pertanyaan (kusioner) yang telah disiapkan. Data sekunder adalah data yang diperoleh dari instansi pemerintah dalam hal ini instansi yang berkaitan dengan kegiatan penelitian.

Penentuan sampel lokasi kecamatan dan desa dilakukan dengan menggunakan metode Purposive Sampling yaitu Kecamatan Tondano
Timur (Desa Papakelan), Tondano Selatan (Desa Tonsaru), Remboken (Desa Talikuran), Kakas Barat (Desa Paso), dan Langowan Timur (Desa Amongena). Kelima kecamatan ini ditentukan dengan pertimbangan bahwa kecamatan tersebut adalah sentra padi dan ternak itik. Penentuan petani sampel secara Simple Random Sampling. Penentuan responden telah dilakukan secara Purposive Sampling dengan kriteria adalah petani sampel yang memiliki kombinasi usahatani padi sawah dan ternak itik. Berdasarkan kriteria tersebut ditentukan 10 (sepuluh) sebagai responden. Analisis data yang telah dilakukan menggunakan analisis keuntungan dilanjutkan dengan analisis $\pi / \mathrm{C}$ ratio.

\section{HASIL DAN PEMBAHASAN}

Hasil penelitian diketahui $80 \%$ responden berumur antara 41 - 50 tahun dan $20 \%$ responden 31- 40 tahun. Ratarata umur responden 45.2 tahun \pm 3.19 . Faktor umur biasanya lebih diidentikkan dengan produktivitas kerja. Menurut Rusli (1995) dalam Lakiu (2012) bahwa umur belum produktif $0-12$ tahun, umur produktif 15-64 tahun dan umur tidak produktif 65 tahun ke atas. Berdasarkan kelompok umur tersebut maka dapat 
dinyatakan bahwa responden dikategori umur produktif.

Hasil penelitian menunjukkan tingkat pendidikan responden sebagian besar adalah tamat SMA/STM (80\%), $10 \%$ tamat SMP dan $10 \%$ tamat SD. Pada umunya tingkat pendidikan responden setara SMA sehingga dianggap cukup untuk menyerap dan menerapkan teknologi baru. Syafa'at, dkk (1995) dan Febriana dan Mairika (2008) menyatakan semakin tinggi tingkat pendidikan petani/peternak maka semakin tinggi kualitas sumberdaya manusia, yang pada gilirannya akan semakin tinggi produktivitas kerja yang dilakukannya. Menurut Edwina, dkk (2006) tingkat pendidikan yang relatif tinggi memungkinkan petani /peternak mampu mengadopsi inovasi, penyuluhan serta bimbingan untuk meningkatkan usahanya.

Pengalaman bertani/beternak responden bervareasi, $20 \%$ responden mempunyai pengalamam $\leq 10$ tahun, $20 \%$ responden 11-20 tahun, 40\% responden 21-30 tahun dan 20\% responden mempunyai pengalaman bertani/beternak $\geq 31$ tahun. Pengalaman berusaha sangat berpengaruh terhadap keberhasilan usaha (Febriana dan Mairika, 2008). Sesuai dengan pendapat Edwina, dkk (2006) semakin lama seseorang memiliki pengalaman berusaha akan semakin mudah mengatasi kesulitan-kesulitan yang dialaminya. Luas lahan garapan tanaman padi umumnya (8 responden atau $80 \%$ ) antara 1 - 2 ha dan $>2$ ha digarap oleh 2 (dua) responden (20\%). Responden yang mempunyai garapan kurang dari 1 ha akan memperluas lahan garapan dengan sistim bagi hasil (Tumoyo).

Hasil penelitian menunjukkan 1 (satu) responden (10\%) memelihara itik berkisar 100 - 200 ekor, 6 (enam) responden $(60 \%)$ memelihara 201 - 300 ekor, 2 (dua) responden (20\%) memelihara 301 - 400 ekor, dan 1 (satu) responden $(10 \%)$ memelihara $>400$ ekor.

Responden memiliki pekerjaan utamanya sebagai petani padi sawah. Beternak masih dianggap sebagai mata pencarian penunjang sehingga curahan waktu terhadap ternak hanya sedikit sehingga berpengaruh terhadap perkembangan usaha peternakan berjalan lambat. Menurut Soejana (1993) dalam Frebriana dan Mairika (2008) bahwa, umumnya penduduk pedesaan mencurahkan perhatiannya pada usaha pokok yaitu sebagai petani sehingga permeliharaan ternaknya kurang diperhatikan. Walaupun usaha ternak 
sebagai usaha penunjang tetapi kenyataannya memberikan sumbangan yang besar bagi pendapatan keluarga tani.

Kombinasi usahatani tanaman dan ternak (Crop-Livestock System) telah terbukti sebagai salah satu sistem produksi yang memberikan penekanan kusus terhadap pertimbangan pertanian berkelanjutan (Adiyoga dkk, 2008). Sistem usahatani campuran dicirikan oleh diversitas dan kompleksitas dari jenis tanaman, ternak dan pola tanam yang digunakan. Berkaitan dengan konteks $C L S$, interaksi tanaman-ternak dapat dibedakan: sistem terdiversifikasi yang bersifat independen satu dengan yang lainnya, dalam pola ini sistem usahatani kombinasi tanaman-ternak cendrung diarahkan terutama meminimalkan resiko, bukan mendaur ulang sumberdaya. Sistem terintegrasi yang bersifat dependen antar komponen yang satu dengan yang lain. Dalam hal ini pengintegrasian diarahkan untuk memaksimalkan kegunaan sumberdaya (Badan Litbang Pertanian, 2010). Sistem kombinasi usahatani tanaman-ternak adalah untuk mencapai kombinasi yang optimum dimana dengan kombinasi tersebut input produksi menjadi terendah (low input) sedang produksi didorong menjadi setinggitingginya.

\section{Menurut Guntoro} (2011), mengusahakan lebih dari satu komoditas, maka resiko usahatani dapat ditekan. Penerapan model kombinasi usahatani tanaman-ternak pada suatu kawasan yang memiliki potensi pengembangan usaha tani campuran harus mempertimbangkan paling sedikit empat skenario, yaitu: 1) skenario alami yang dilakukan atau dipraktekan oleh petani setempat. 2) skenario sistem usahatani tanpa ternak. 3) skenario usahatani dengan ternak, dan 4) skenario yang berbasis sumberdaya (lahan, tenaga kerja, dan modal).

Tabel. 1. Rataan Biaya dan Penerimaan Kombinasi Usahatani Padi sawah dan Itik Petelur

\begin{tabular}{|c|c|c|}
\hline No & Uraian & Total (Rp) \\
\hline \multirow[t]{4}{*}{1} & Penerimaan & \\
\hline & Usahatani Padi Sawah & 23820333 \\
\hline & Usaha Ternak Itik Petelur & 51726300 \\
\hline & Jumlah & 75546633 \\
\hline \multirow[t]{4}{*}{2} & Pembiayaan & \\
\hline & Usahatani Padi Sawah & 14122146 \\
\hline & Usaha ternak Itik Petelur & 34891750 \\
\hline & Jumlah & 49013896 \\
\hline \multirow[t]{2}{*}{3} & Keuntungan & 26532737 \\
\hline & $\pi / \mathrm{C}$ Rasio & 1.54 \\
\hline
\end{tabular}


Hasil penelitian Abduh dkk (2003) menunjukkan ternak itik yang digembalakan disawah dan diberipakan tambahan produksinya dan produksi padi pada sawah yang digembalakan itik cendrung lebih tinggi. Ha lini memberikan kenyataan terdapat timbal balik (interaksi) dari kombinasi usahatani padi sawah dan ternak itik. Sampai saat ini masih banyak itik petelur yang dipelihara secara tradisional, yaitu digembalakan secara berpindah dari satu lokasi sawah setelah panen ke lokasi lainnya (Zuraida. 2004). Keuntungan yang diperoleh dari mengkombinasikan usaha tani padi-ternak itik, meliputi: 1) berkurangnya biaya produksi akibat penurunan penggunaan pupuk, pestisida serta upah tenaga kerja untuk menyiang rumput. 2) padi/beras yang dihasilkan berkualitas baik. 3) peningkatan mutu kan kondisi lahan. 4) Biaya produksi itik menjadi lebih rendah karena sebagian besar sumber pakan berasal bahan lokal.

Suatu usahatani dapat dikatakan layak atau tidak untuk dilaksanakan dapat dilihat dari efisiensi penggunaan biaya dan besarnya perbandingan antara total penerimaan dengan total biaya (Maulidah. 2012). Hasil penerimaan kombinasi usahatani padi sawah dan ternak itik diperoleh dari penjumlahan penerimaan usahatani padi sawah dan usaha ternak itik petelur, seperti tertera pada Tabel 1.

Data pada Tabel 1 menunjukkan bahwa penerimaan kombinasi usahatani padi sawah dan ternak itik sebesar Rp 75546633.-per tahun dan total pembiayaan sebesar Rp 49013896.-per tahun. Penerimaan dari usahatani padi dari penjualan GKG. Sedangkan penerimaan usaha ternak itik dari penjualan telur itik dan itik afkir. Keuntungan dari kombinasi usahatani padi sawah dan ternak itik sebesar Rp 26532737.-per tahun.

\section{KESIMPULAN}

Berdasarkan hasil pnelitian dapat disimpulkan bahwa usahatani padi yang dikombinasikan dengan ternak itik memberikan keuntungan yang memadai dengan $\pi / \mathrm{C}$ ratio lebih besar satu. Berdasarkan hasil penelitian disarankan agar usahatani padi sawah sebaiknya dikombinasikan dengan usahaternak ini.

\section{DAFTAR PUSTAKA}

Abduh. U., A. Ella dan A. Nurhayu. 2003. Integrasi Ternak Itik Dengan 
Sistem Usahatani Berbasis Padi

Di Kabupaten Sidrap Sulawesi

Selatan.Seminar Nasional Sistem

Integrasi Tanaman - Ternak.

Hlm. 224-229.

Adiyoga. T., A. Soetiarso, dan M. Meriana.2008. Interaksi

Komponen Dalam Sistem usahatani Tanaman-Ternak Pada Ekosistem Dataran tinggi di Jawa barat. J. Hort. Vol. 8. N0. 2. 2008

Badan Litbang Pertanian. 2010. Prospek dan Arah pengembangan Agribisnis Unggas. Departemen Pertanian. Jakarta.

Edwina, S., Cepriadi dan Zainia. 2006. Analisis Pendapatan Peternak Ayam Broiler Pola Kemitraan di Kota Pakan Baru. Jurnal Peternakan Vol 3 N0 1 Februari 2006.

Febriana, D dan L. Mairika. 2008. Pemanfaata Limbah Pertanian Sebagai Pakan Ruminansia Pada Peternakan Rakyat Di Kecamatan Rengat Barat Kabupaten Indragiri Hulu. Jurnal Peternakan Vol 5 N0 1 Februari 2008 (28 - 37). ISSN 1829 8729.
Guntoro.S., 2011. Pertanian Tekno Ekologis. PT. Agro Media Pustaka. Jakarta.

Lakiu, P.B. 2012. Analisis kelayakan kombinasi usahatani penggemukan ternak sapi dengan komoditi padi sawah dan kakao di kecamatan pamona selatan.Tesis

Prog.Pascasarjana.Unsrat.

Maulidah. S. 2012. Pengantar Usahatani: Kelayakan Usahatani. Lab.Of Agribusiness Analysis and Management. Faculty Of Agriculture. Universitas Brawijaya.

Syafa'at, N.P. Simatupang, S. Mardianto dan T. Pranaji. 2003. Konsep Pengembangan Wilayah Berbasis Agribisnis Dalam Rangka Pemberdayaan Petani. Forum Penelitian Agro Ekonomi 21 (1) : 26-43.

Zubaidah. 1991. Performans produksi telur hasil persilangan itik Alabio dengan itik bibit induk CV 2000 pada generasi pertama. Tesis. Fakultas Pascasarjana. Institut Pertanian Bogor, Bogor. 